\title{
A Review of Emerging Technologies for an Assessment of Safety and Seismic Vulnerability and Damage Detection of Existing Masonry Structures
}

\author{
Mislav Stepinac ${ }^{1, *(D)}$ and Mateo Gašparović ${ }^{2}$ (D) \\ 1 Faculty of Civil Engineering, University of Zagreb, 10000 Zagreb, Croatia \\ 2 Chair of Photogrammetry and Remote Sensing, Faculty of Geodesy, University of Zagreb, \\ 10000 Zagreb, Croatia; mgasparovic@geof.unizg.hr \\ * Correspondence: mislav.stepinac@grad.unizg.hr
}

Received: 3 July 2020; Accepted: 21 July 2020; Published: 23 July 2020

check for updates

\begin{abstract}
The construction sector has proven to be one of the slowest sectors to embrace technology - a problem that must be addressed. This problem can be quickly and efficiently addressed in certain aspects of seismic engineering: from seismic risk assessment to damage detection, as well as condition assessments existing structures before or after an earthquake. In this paper, the literature review of assessment methods and damage detection technologies for existing (mainly) masonry structures is presented. Traditional methods are briefly explained, and modern are critically discussed. Special focus is given to unmanned aerial vehicles, as well as, photogrammetry and close-range remote sensing as a technology that can complement traditional ways of assessment and give us data about a structure that is often different to obtain. Graphical interpretation of one post-earthquake case study is provided. Open challenges and opportunities of emerging technologies for faster and easier assessment of seismic safety and vulnerability are presented.
\end{abstract}

Keywords: earthquake; vulnerability; unmanned aerial vehicle; damage detection; assessment; photogrammetry; close-range remote sensing

\section{Introduction}

Earthquake is an unpredictable and unexpected natural disaster that results in the devastation of both natural and human-made environments. Studying the complexity of an earthquake, including its prediction and its consequences, requires knowledge from various areas of scientific study, ranging from seismology, geology, geodesy, mathematics, and applied statistics all the way to psychology, humanities and social science and of course, structural engineering.

The seismic risk of a structure is a measure of the expected future damage caused by the earthquake, which is expected to occur in the site of construction. It depends on three factors: hazard, vulnerability, and exposure [1,2]. Most casualties from earthquakes are associated with collapsing buildings. In this regard, the continuous assessment and monitoring of the seismic safety and vulnerability of buildings is a challenging task, especially when large-area evaluations are required [3]. The construction sector plays a significant role in the alleviation of the effects and consequences caused by earthquakes and new technologies, products, systems, design approaches are regularly introduced to a broader community [4-12].

It is generally assumed that an earthquake cannot be predicted (although it can be expected) or simulated (although we can approximate it), and that its destructive effects cannot be prevented (although they can be minimized or, at worst, optimized). However, building our infrastructure with the basic state-of-the-art (STAR) principles in mind will provide us with the ability to keep it safe 
from a predicted level of seismic activity (a detail frequently overlooked) and, more importantly in the seismic design to save lives. The importance of seismic design is to protect property and life in buildings. But to have a proper seismic design, we need to learn from existing structures.

The construction sector is the slowest one to appropriate new technologies [13,14] —and this is something that should be changed. This motivates the quest for finding the technological solution for the safety assessment of existing structures. As the least innovative sector, civil engineering must appropriate technological advances from other disciplines in order to be able to keep up with them. This applies to all aspects of the sector, from construction and planning to seismic and safety assessment.

In this paper, the literature review on modern technologies for the assessment of seismic safety and vulnerability of existing structures will be explained. Special focus will be set on unmanned aerial vehicles (UAV) and supporting equipment, as well as, photogrammetry and close-range remote sensing.

\section{The Assessment Methods for Condition Inspection and Identification of Seismic Vulnerability of Existing Masonry Buildings}

Regarding economy and sustainability, it is of great significance for a society to maintain existing building stock instead demolish and rebuild them. The contribution of the assessment phase to the decision-making process is crucial for the correct assessment, verification, and maintenance of existing buildings [15-17].

The assessment of an existing structure can be done in various stages with increased accuracy, the level of accuracy, thereby depending on the quantity and the quality of available data as well as on the significance of the structure. The developments in the areas of inspection, nondestructive techniques (NDT), structural health monitoring (SHM), and structural analysis of existing structures, together with recent guidelines for reuse and conservation, allow for safer, economical and more adequate remedial measures [18].

The assessment techniques focus mainly on damage identification, damage localization, and damage evaluation, as well as the determination of certain material properties of existing structures. There are several new NDT and semi-NDT methods on the market, different in sophistication and purpose. As the focus of this research is mainly on masonry structures or combined masonry and concrete/timber structures, the most important NDT methods for existing masonry structures can be summarized: visual inspection [19], rebound hammer [20,21], measurement of reinforcement location [22], stress wave transmission [23], ultrasonic velocity testing [24], sonic velocity testing [25,26], surface penetrating radar [25,27], infrared thermography [28], flatjack tests [29,30], damage identification using impact vibrations [31], acoustic emission [32], etc. The basic advantages and disadvantages of the mentioned methods are described in Table 1. More detailed information can be found in [33].

The issue of seismic vulnerability assessment and restoration of underperforming existing buildings is a very significant and difficult problem [34]. To develop efficient assessment methods, it is necessary to draw knowledge and information from various other scientific fields. The seismic vulnerability requires specialized technical skills [35].

The preliminary work on seismic assessment was based only on visual inspection of the buildings [19,36], NDT [15,24,32,37,38], and the experience of an engineer. The last decade has seen a growth in the technological advancement of various instruments that can considerably help in the estimation of structural safety and seismic behavior of existing structures. The applicability of the thermal camera for building diagnostics and detection of energy-related building defects has been investigated by numerous authors [39-44]. The importance close-range remote sensing and using multispectral cameras for damage assessment and crack detection on buildings was emphasized by numerous researchers [45-47]. In the last few years, a growing number of studies have shown the great potential of hyperspectral cameras for detection and mapping cracks on buildings $[48,49]$. Unmanned aerial vehicles (UAV) can be used for i.e., disaster management $[50,51]$, crack identification using image processing [47,52], seismic vulnerability [53], architectural assessment 
of heritage sites and structures [54], and structural assessment using image processing techniques [55]. UAV-based photogrammetry [56-58] and LiDAR (Light Detection and Ranging) [59-61] devices are indeed used after earthquakes to scan affected areas, but this method is mostly used for larger areas only. The advantages and disadvantages of the new technologies which should complement traditional methods are given in Table 2. Mentioned techniques are especially proven to be good at a post-earthquake evaluation of the complete urban/rural areas and buildings individually.

Table 1. Basic advantages and disadvantages of NDT and semi-NDT inspection methods for existing masonry structures.

\begin{tabular}{|c|c|c|}
\hline Method & Advantages & Disadvantages \\
\hline Visual inspection & $\begin{array}{ll}\text { - } & \text { Cheap } \\
\text { - } & \text { Fast (or no) preparation } \\
\text { - } & \text { Immediate results } \\
\text { - } & \text { Non-destructive }\end{array}$ & $\begin{array}{l}\text { - } \quad \text { Skilled working force needed } \\
\text { - } \quad \text { Detection of only larger defects } \\
\end{array}$ \\
\hline Stress wave transmission & $\begin{array}{l}\text { - The presence of reinforcements or moisture do } \\
\text { not affect the results } \\
\text { - Non-destructive }\end{array}$ & $\begin{array}{l}\text { - The results should be used for qualitative purposes } \\
\text { - } \quad \text { Highly affected by moisture and salt content }\end{array}$ \\
\hline $\begin{array}{l}\text { Ultrasonic \& sonic velocity } \\
\text { testing, acoustic emission }\end{array}$ & $\begin{array}{l}\text { - Fast and higher accuracy in results } \\
\text { - Non-destructive method } \\
\text { Accessibility to just one side of the } \\
\text { element needed } \\
\text { - Not affected by moisture }\end{array}$ & $\begin{array}{l}\text { - } \quad \text { High skilled and educated working force needed } \\
\text { - } \quad \text { Mrsreading of signals } \\
\text { - } \quad \text { Transducers must be coupled on the material surface } \\
\text { - } \quad \text { Thall defects can affect results } \\
\quad \text { wave speed is automatically calculated }\end{array}$ \\
\hline Impact echo & $\begin{array}{l}\text { - } \quad \text { Non-destructive method } \\
\text { Accessibility to just one side of the } \\
\text { element needed }\end{array}$ & $\begin{array}{l}\text { - Slow method - requires a lot of measurements to map } \\
\text { - } \quad \text { Streser regions } \\
\text { - }\end{array}$ \\
\hline Surface penetrating radar & $\begin{array}{l}\text { - Cracks, bonds, delamination does not affect } \\
\text { the results } \\
\text { - Fast method } \\
\text { - Non-destructive method } \\
\text { - Possibility to investigate different conditions } \\
\text { such as salt content and moisture content, } \\
\text { location of reinforcements, deterioration, etc. }\end{array}$ & $\begin{array}{l}\text { - } \quad \text { Relatively expensive } \\
\text { Mortar interfaces can mask energy reflected from } \\
\text { points of interest }\end{array}$ \\
\hline Rebound hammer test & $\begin{array}{ll}-\quad & \text { Ease of use } \\
\text { - } & \text { Relatively cheap } \\
\text { - } & \text { Fast method }\end{array}$ & $\begin{array}{l}\text { - } \quad \text { Results are for a local point } \\
\text { - The results are not directly related to the strength } \\
\text { of surface } \\
\text { - } \quad \text { Affected by surface and moisture condition } \\
\text { assessment of concrete structures) } \\
\text { - Not completely NDT - leaves a little hole in the } \\
\text { masonry unit }\end{array}$ \\
\hline Flatjack system & $\begin{array}{l}\text { - Gives compressive strength with } \\
\text { reasonable accuracy } \\
\text { Ease of use }\end{array}$ & $\begin{array}{l}\text { - } \quad \text { Semi-destructive method } \\
\text { - } \quad \text { Time-consuming } \\
\text { - } \quad \text { Drilling and cutting is not always easy (especially for } \\
\text { - } \quad \text { Requires repair of a mortar joint } \\
\text { - } \quad \text { Frequent calibration required }\end{array}$ \\
\hline
\end{tabular}


Table 2. Basic advantages and disadvantages of new technologies for the rapid assessment of the vulnerability of structures.

\begin{tabular}{|c|c|c|}
\hline Technology/Method & Advantages & Disadvantages \\
\hline UAV & $\begin{array}{ll} & \\
- & \text { Fffordable } \\
\text { - } & \text { Ease of use } \\
- & \text { Immediate results } \\
- & \text { Nondestructive } \\
- & \text { Constant improvement of technology } \\
- & \text { Safety-remote control of the vehicle } \\
\text { - } & \text { Available inspection of literally any place of } \\
& \text { the building }\end{array}$ & $\begin{array}{l}\text { - Limited battery capacity } \\
\text { - } \quad \text { Depends on weather conditions } \\
\text { - } \quad \text { Legal restrictions related to drone flight } \\
\quad\end{array}$ \\
\hline LiDAR & $\begin{array}{l}\text { - } \quad \text { Data can be collected quickly and with } \\
\text { great precision } \\
\text { - } \quad \text { Can be used during the day and night } \\
\text { - } \quad \text { Mostly independent of weather conditions } \\
\text { - } \quad \text { Noncomplex postprocessing } \\
\text { - 3D data acquiring }\end{array}$ & $\begin{array}{l}\text { - Unprofitable for detecting small building cracks } \\
\text { - } \quad \text { Ineffective in heavy rain } \\
\text { - } \quad \text { Price } \\
\text { - Non or low-quality textures }\end{array}$ \\
\hline High-resolution cameras & $\begin{array}{l}\text { - } \quad \text { Quickly available data } \\
\text { - } \quad \text { High quality and precision photography }\end{array}$ & $\begin{array}{l}\text { - Price } \\
\text { A large amount of data and sometimes takes a long } \\
\text { time to get useful information }\end{array}$ \\
\hline Infrared thermography & $\begin{array}{ll}\text { - } & \text { Rapid evaluation of big areas } \\
\text { - } & \text { NDT method } \\
\text { - } & \text { Real-time measurements }\end{array}$ & $\begin{array}{l}\text { - High skilled and educated working force needed } \\
\text { - } \quad \text { Affected by moisture content, texture, or reflections } \\
\text { - } \quad \text { Relatively expensive }\end{array}$ \\
\hline Photogrammetry & $\begin{array}{l}\text { - } \\
\text { - } \quad \text { Cheap, simple, and fast data collection process } \\
\text { - } \quad \text { Very precise } \\
\text { - } \quad \text { it is possible to measure displacements and } \\
\text { deformations of structures without contact } \\
\text { High-resolution photorealistic 3D } \\
\text { building models } \\
\text { - } \quad \text { High-resolution textures } \\
\quad \text { Better for smaller building cracks detection } \\
\quad \text { compared to LiDAR }\end{array}$ & $\begin{array}{l}\text { - Not possible without the presence of light (during } \\
\text { the day) } \\
\text { - } \quad \text { Depends on the weather conditions } \\
\text { - } \quad \text { Large data sets } \\
\text { - } \quad \text { Complex postprocessing } \\
\text { - Required postprocessing to get 3D data }\end{array}$ \\
\hline 360 cameras & $\begin{array}{l}\text { - Fast and efficient technology } \\
\text { - Can be mounted on vehicles that are then } \\
\text { passed through the area affected by } \\
\text { the earthquake. } \\
\text { Possible to create an online platform (such as } \\
\text { Google Street View) where earthquake damage } \\
\text { can be identified and documented }\end{array}$ & $\begin{array}{l}\text { - If the distances at which the photos were taken are } \\
\text { large or the vehicle is moving too fast, there may be a } \\
\text { problem connecting the images } \\
\text { - Vegetation and certain objects can create problems } \\
\text { when taking photos } \\
\text { - Inability to detect roof damage } \\
\text { Unprofitable for detecting small building cracks }\end{array}$ \\
\hline
\end{tabular}

\section{UAV Platform for Multi-Sensor Photogrammetry Aerial Mapping}

Nowadays, technology and sensor minimization enable the development of the multi-sensor custom-made UAVs (unmanned aerial vehicles) for multi-sensor aerial mapping. As already mentioned, UAVs can be applied to acquiring spatial data about the condition of buildings [59], cultural heritage [56], but also for acquiring spatial data of larger areas for risk assessment of damage detection and mapping, e.g., after earthquakes [57,58]. These platforms are equipped with the newest sensors for in-flight position determination. These sensors include GNSS (Global Navigation Satellite System), RTK (real-time kinematic), and IMU (inertial measurement unit) systems that allow positioning in centimeter accuracy in real time. Today, significant importance in the development of the UAV platform was devoted to developing new technologies for stabilization and orientation of the multi-sensor system [62-64]. The UAV platforms for multi-sensor aerial mapping can be made based on the open-source or commercial flight controllers and technologies and are able to carry out mapping missions autonomously [65-67]. For high-accuracy photogrammetric measurement of the safety 
and seismic vulnerability of existing structures, the systems are equipped with sensors that measure the obstacle distance and therefore enable flights at a close distance to buildings (e.g., microradar and/or LiDAR). Furthermore, these systems are the foundation for fast and accurate collection of large amounts of spatial data for building damage detection and mapping. In Figure 1, one scenario of the post-earthquake assessment with a UAV is shown. An engineer cannot see what happened to a building at higher floors or roof of a structure when doing on-site assessment from the street. Very often, the main problems (especially for moderate intensity earthquakes) are chimneys, damaged roof structures, damaged gable walls, etc. With a UAV device, all of the mentioned information can be easily assessed.

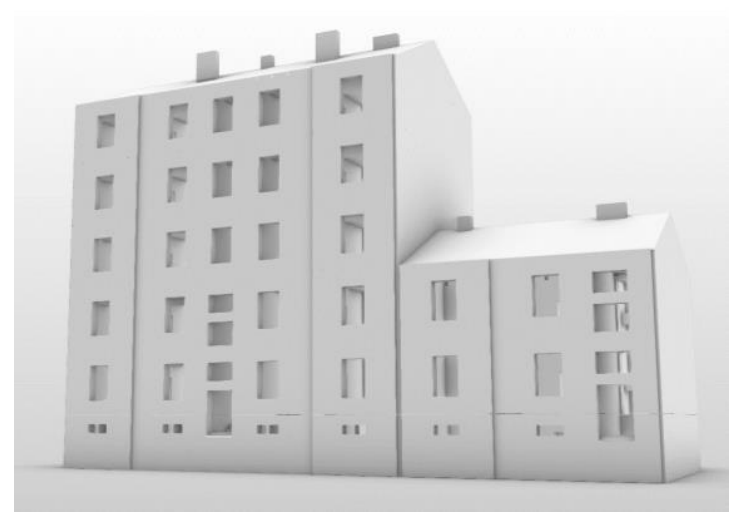

(a)

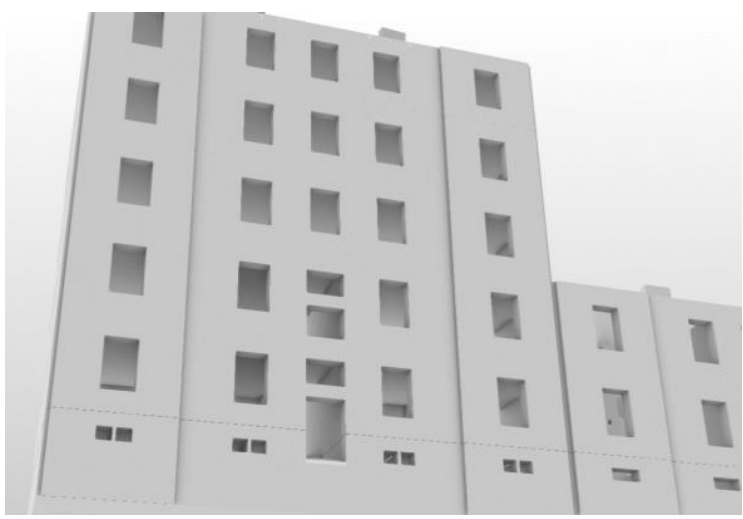

(b)

Figure 1. Cont. 


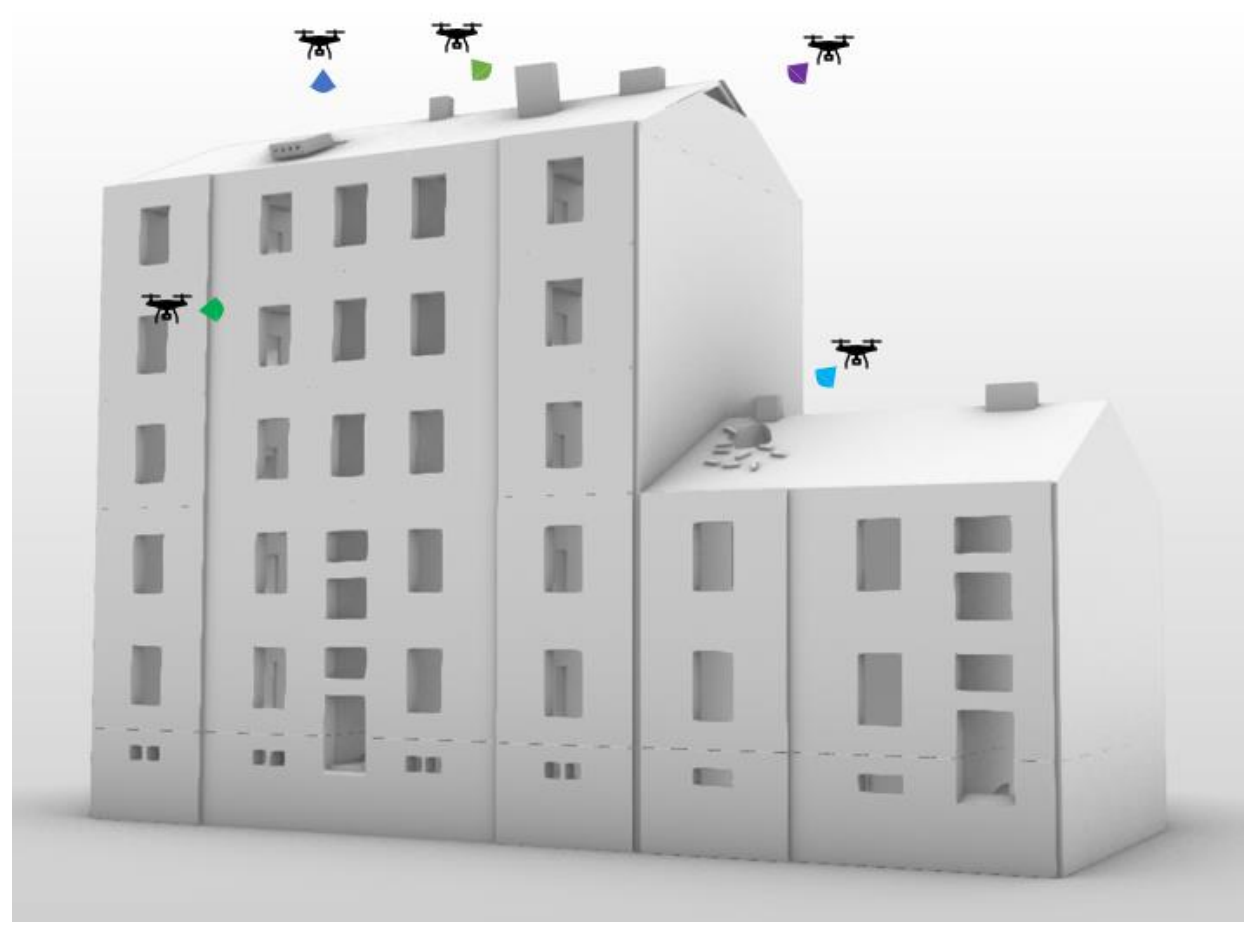

(c)

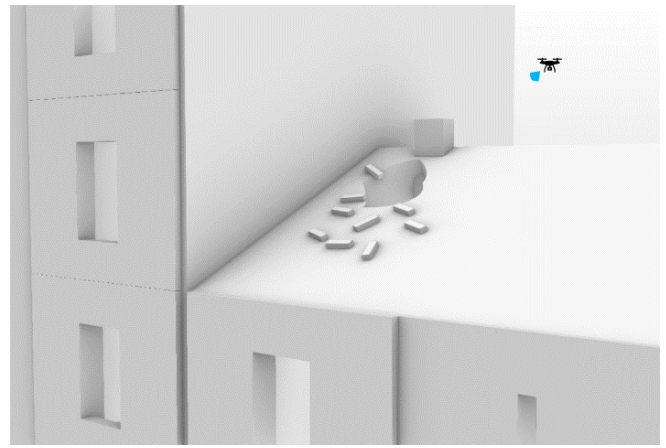

(d)

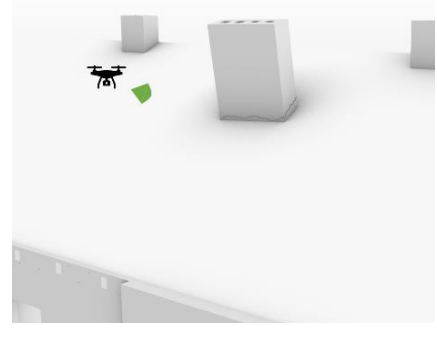

(f)

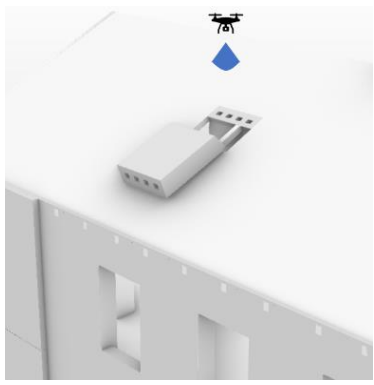

(g)

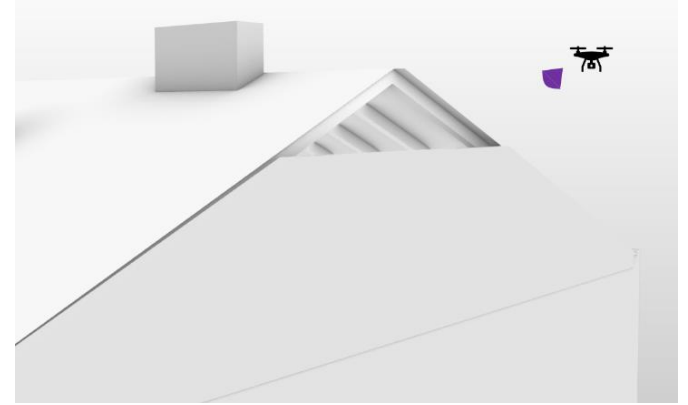

(e)

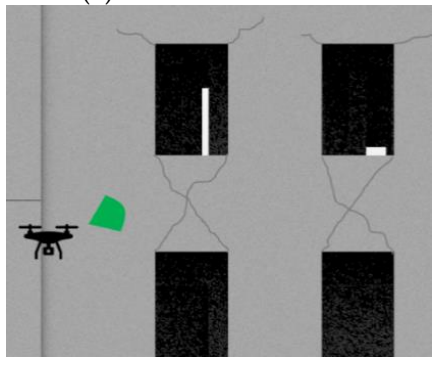

(h)

Figure 1. Photogrammetric multi-sensor systems on UAVs enable a fast and accurate collection of large amounts of spatial data for building damage detection and mapping. (a) Undamaged building, (b) visual inspection from street level, (c) post-earthquake assessment with UAV systems, (d-h) possible damages on a building after an earthquake.

\subsection{Multi-Sensors System for Photogrammetry Data Acquisition}

The aforementioned advances in technology and sensor minimization give us the opportunity to the development of unique, highly specialized multi-sensors system for photogrammetry data acquisition. Today, these systems can contain four independent types of cameras: RGB camera, thermal, multispectral, and hyperspectral camera. All these cameras complement each other in spectral, 
radiometric, and geometric characteristics. The new multi-sensor system is capable for the detection of damage and anomalies on a building that is not visible to the human eye. The importance of using various kinds of different cameras, from thermal to multispectral cameras for damage assessment and crack detection on buildings, was emphasized by numerous researchers [48,52]. Although all these cameras were already used for building diagnostics assessment, so far, a multi-sensor system has not been developed for this purpose. It should be noted that the multi-sensor system should be modular, and it should be able to use different camera lenses, depending on building size and a priori accuracy. The newly built multi-sensor system should enable accurate data acquisition for building damage assessment, and the system harness the potential of all implemented cameras.

After the design and development of the multi-sensor system, it is necessary to develop new methods for calibration, synchronization, and fusion of the collected data. For each camera, the development of the new calibration method based on photogrammetric methods must be obtained. The geometric calibration for internal camera parameters calculation must be done $[68,69]$ and followed by the radiometric calibration for each camera [70-73]. Further, for the autonomous spatial data acquisition from all cameras in a multi-sensor system, the system synchronization is crucial $[70,74,75]$. Adequately synchronized multi-sensor system are able to autonomously and/or remotely capture images from all cameras at the same time. Once the data has been properly collected, it is necessary to research and develop new imagery fusion methods. The new fusion methods developed for the multi-sensor system with various independent cameras allow the collection of a fused image that contains the data of all the above sensors (visible part of the spectrum, thermal, multispectral and hyperspectral data). The fusion process increases the spatial resolution of final multi-band imagery. The usage of fused, high-resolution, multi-band imagery enables better and more accurate damage detection on buildings.

\subsection{Remote Sensing Methods for Automatic Detection and Mapping of Weak Structural Parts and Components}

After the multi-sensor system has collected the data, to speed up the process, the mapping of weak structural parts and components should be performed. Such methods allow for the rapid analysis of large amounts of spatial data, which cannot be processed manually. The current development of new methods is based primarily on the analysis of all available data of the multi-sensor system. Taking advantage of individual bands outside the visible spectrum, such as images captured by a thermal, multispectral, and hyperspectral camera, enable detection, highlighting, and mapping of features that are not visible to the human eye $[45,46]$. The use of fused imagery further enhances the spatial resolution of the imagery and enables the detection of even the smallest cracks in the object $[76,77]$. The development and use of these methods enable rapid detection and accurate mapping of the smallest cracks that may not be visible on the objects themselves. The application of developed methods significantly accelerates the process of gathering information on the structure and condition of existing buildings.

\subsubsection{Photogrammetric Three-Dimensional (3D) Building Modeling Methods}

Optimal photogrammetric methods need to be developed for an accurate and measurable high-resolution photorealistic 3D building model based on a multi-sensor system and GeoSLAM system [78]. Photogrammetric methods are primarily based on an adequate phototriangulation procedure for all images. During the process of phototriangulation, the self-calibration of cameras control the stability of their internal elements [71]. The development of methods for the rapid creation of 3D models include the test of sensor accuracy for determining the elements of the external orientation of real-time images (GNSS + RTK, IMU) [62,69]. Markers can be used on the objects to control the phototriangulation process and the final 3D model. Nowadays, indoor spatial data for 3D models are usually acquired with the GeoSLAM system. The final 3D model can be made by the combination of data acquired with the multi-sensor system and GeoSLAM system data. Furthermore, spectralon and other markers to perform radiometric calibration can be placed on the objects [71]. This ensures the accuracy 
of the spectral signature of the recorded objects. For controlling thermal images, the temperature of the object can be measured by a measuring device and sensors at the time of data collection. This enables obtaining an accurate 3D model in the thermal spectrum, i.e., the accuracy of the temperature obtained by the multi-sensor system. The development and implementation of methods for photogrammetric creation of SfM (Structure-from-motion) point clouds enable the creation of high-resolution, dense 3D point clouds [79-81]. The dense point clouds are filtered by newly developed outlier detection algorithms for gross error points detection (e.g., glass area) [82-84]. For quality and accurate point cloud collection on objects with uniform textures, methods for radiometric enhancement of textural features were developed. Radiometric equalization of photogrammetric images based on new methods allow for the creation of seamless photorealistic 3D models $[85,86]$. Further, with new 3D modeling methods, the point cloud can be transformed into a high-resolution photorealistic 3D building model (Figure 2).

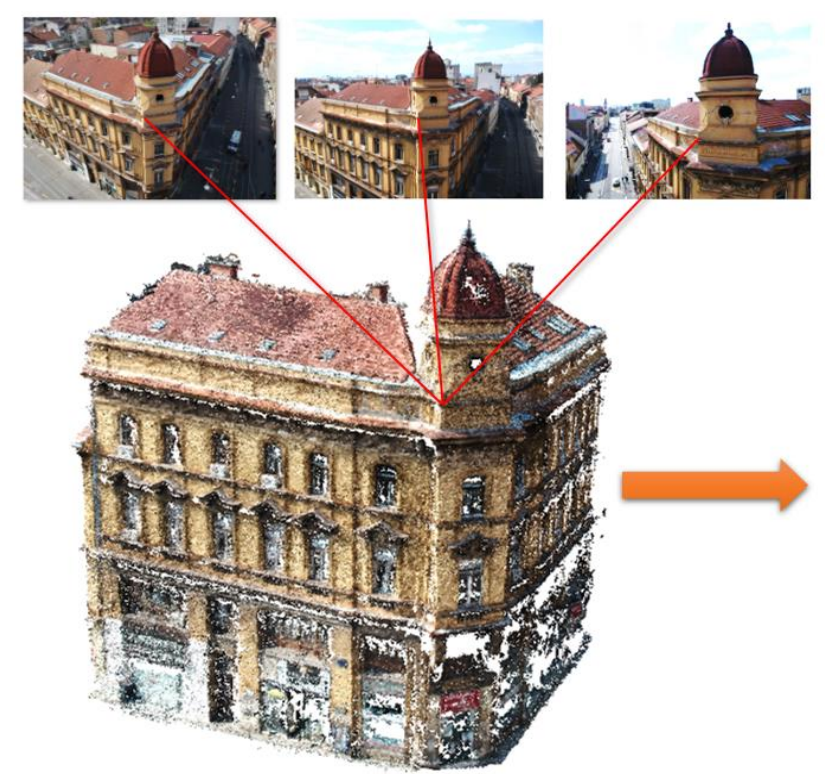

(a)

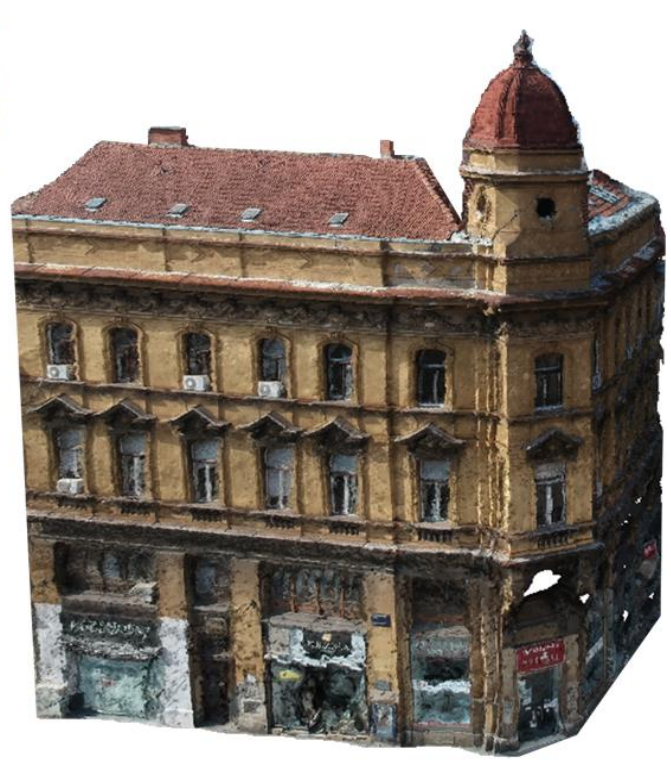

(b)

Figure 2. Photogrammetric 3D building modeling methods. From (a) photogrammetric creation of SfM (Structure-from-motion) point clouds to the (b) high-resolution photorealistic 3D building model.

\subsubsection{Automatic Methods for Building Damage Detection and Mapping}

The photorealistic 3D models and products (e.g., from orthophoto) can be used for the detection and mapping of building damage. The developed methods are based on a combination of unsupervised and supervised image classification methods. Furthermore, the methods can be technologically developed on object-based machine learning algorithms [87-90]. Such an approach allows rapid damage detection on buildings, which is important because of the large amount of high-resolution spatial data. Preliminary research related to the topic of developing automatic methods for the classification has been made [91]. Newly developed methods for the detection and mapping of building damage can use all bands of the multi-sensor system, but also spectral indices. Spectral indices allow further highlighting of certain phenomena on earth or objects [91-93]. The use of spectral indices has been shown to increase the accuracy of classifications. In some cases, spectral indices allow features to be highlighted on an object that cannot be detected on any single band in the visible or out of the visible part of the spectrum. In addition to the spectral indices, the newly developed methods also use the Haralick texture features (Gray Level Co-occurrence Matrix) to detect and emphasize the edge between damaged and undamaged parts on objects [94-98]. Using an object-based approach enables rapid and accurate mapping of damage. After the mapping, the system immediately assigns statistical indicators such as area, depth, etc. (Figure 3). The development of a new automatic method for structural damage 
detection and mapping is a major scientific contribution in the field of photogrammetry and remote sensing applications in civil engineering.

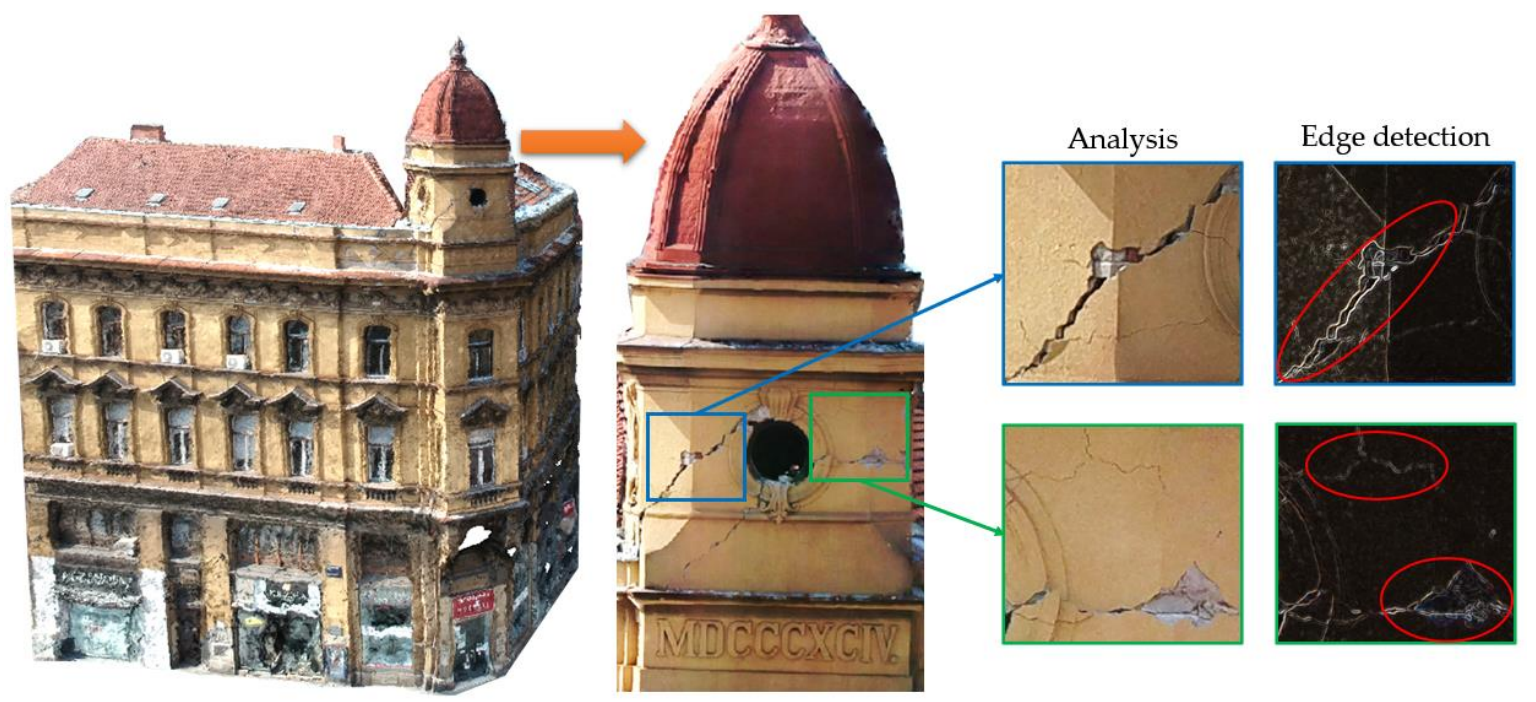

Figure 3. Automatic building damage detection and mapping based on the photogrammetric 3D methods and remote sensing techniques.

\section{Discussion and Conclusions}

The knowledge of seismic behavior of structures has seen significant advancements in recent decades. Still, there is much left to be considered. We are still unfamiliar with a number of things that must be taken into account, such as the magnitude, direction, and scale of earthquakes themselves, as well as their stochastic (random) nature. Some fundamental decisions still need to be made, e.g., whether to opt for deterministic or probabilistic modeling, static or dynamic load modeling, linear or nonlinear seismic behavior of structures.

Are we able to minimize the effects of an earthquake, or is optimizing them still the only option? How much do we know about the seismic risk or the potential consequences of seismic activity on our infrastructure? How accurate are we in assessing the seismic vulnerability of existing buildings? Alas, most of these questions remain unanswered as more research needs to be done on seismic risk and seismic vulnerability assessment. Concentrating only on visible issues cannot resolve this questions.

Conventional approaches only allow us to assess the condition of an existing structure once its stability has already been compromised. They also only help us when we know from experience that a certain building is vulnerable to seismic activity. But what about any invisible parameters? Are we ready to appropriate new technologies in the engineering sector? Can the use of thermography and UAVs help us expand our abilities in seismic vulnerability assessment? Can any new methods point us to other parameters crucial to the development of this scientific field? How do we precisely characterize data gathered with the help of new technologies? Answering these questions may give way to new principles in the field and foster the use of new technologies of photogrammetry and close-range remote sensing much needed in such a traditional sector as civil engineering.

Insight in material and structural properties obtained by assessments and structural analyses and evaluation can help us is in modeling, analyzing, and predicting the performance of existing structures and is always a base for the preparation of the data for more precise analyses. However, it is not always possible to have a comprehensive on-site assessment for rapid evaluation of buildings.

The basic idea of this paper is to show the possibilities for the development of an easy and fast procedure for seismically generated damage detection of buildings with new technologies such as UAVs and optical inspections. The open questions and possible future trends in the assessment of the seismic vulnerability of the existing structures is also discussed. The seismic vulnerability of a structure 
is a quantity associated with its weakness in the case of earthquakes of a given intensity so that the value of this quantity and the knowledge of seismic hazard allows us to evaluate the expected damage from future earthquakes [99]. In modern assessment methods, the seismic vulnerability is represented by vulnerability curves, considering, in individual cases only, some structural characteristics of the affected buildings [100]. Throughout history, a variety of methods have been used to assess the vulnerability that can be divided into empirical and analytical (both approaches can also be used in different hybrid methods) and an approach based on engineering judgment by experts. Methods of vulnerability assessments mainly model damage to a discrete scale of damage commonly using three to six categories [101], but still, there are no unified approaches on a European level. High-definition precision images of buildings using satellites, LiDARs, drones, Google Street View and the like can give us information on floor dimensions, height, floors, etc. It is important to emphasize that such information alone is not sufficient, and it needs to be processed by experts, but also supplemented by other data relevant for damage assessments (e.g., structural system, function, and usage).

A compilation of all the data can be obtained to get a unique view of the seismic vulnerability of existing structures. A combination of the data from "traditional" assessments with the results from modern techniques can help us in the identification of weak structural parts and components (faults, big cracks, and openings, short cantilevers, and walls, short columns, soft storeys). With the knowledge of the architectural background and styles of the city, a quick estimation of the period when the building was built can be obtained, i.e., in Croatia, tall windows can tell us that the building was built during the Austro-Hungarian times. This data can relate to construction methods, wooden ceilings, lack of glazing and confiners, greater wall thickness, different material quality, etc. All these important factors are influencing the seismic behavior of the existing structure. With measurement data of foundation settlings, soil stiffness can be assessed or may indicate some differential settling. In addition, the building stiffness can be estimated, which can lead to an estimation of the number of internal walls. Assessment of roofs with UAVs can identify the deformation of roof plates and can serve as a basis for the identification of internal walls, which can also lead to estimation of stiffness. With thermography, different building materials can be identified (masonry vs. concrete) and existing confining elements with their dimensions and location in the structures can be pointed out. With a combination of methods, and estimation of wall thicknesses (with basic geometry) quick interpretation of structural safety can be estimated. Deformation of outer walls obtained by photogrammetry combined with energy losses by thermography and architectural rules of the construction period, and with expert opinions can lead us to a rough estimation of the number of walls (considering the knowledge of load-bearing plate system). All of the mentioned activities can give us the level of seismic vulnerability and safety of the existing structures. The obtained data, new procedures, and techniques can help us in the estimation of seismic risks of bigger regions or building blocks (Figure 4).

A conceptual design of building blocks can be easily identified (weak parts, floors on different heights, and influence of one building to another), which gives the information of seismic risk.

The development of a modern procedure for structural damage detection and estimation of seismic risk and vulnerability must be improved with new and accessible technologies. 


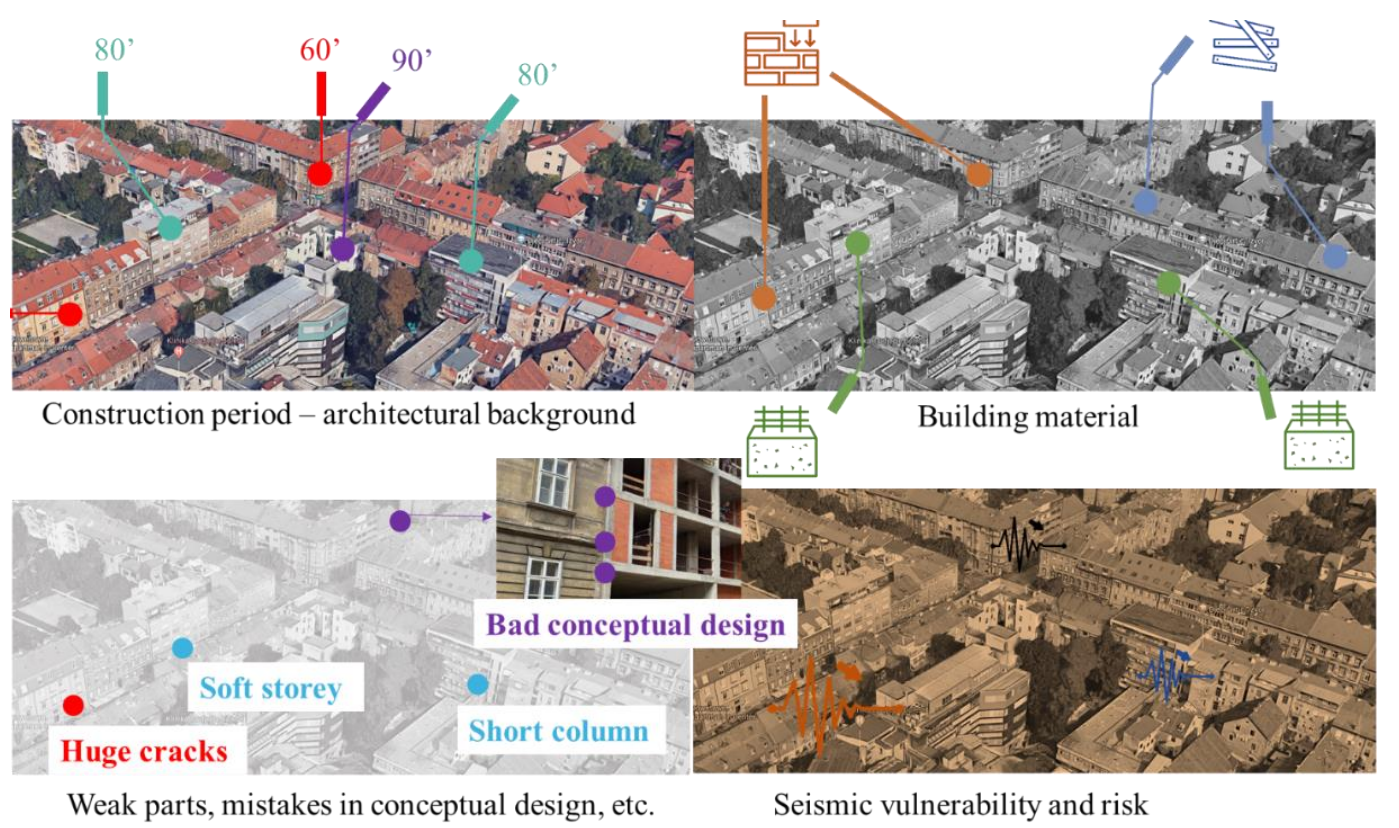

Figure 4. Predicting the seismic vulnerability of buildings and seismic risk of building blocks with the combination of various data.

Author Contributions: Conceptualization, M.S. and M.G.; methodology, M.S. and M.G.; validation, M.S. and M.G.; formal analysis, M.S. and M.G.; investigation, M.S. and M.G.; resources, M.S. and M.G.; photo credit, M.S. and M.G.; writing-original draft preparation, M.S. and M.G.; writing-review and editing, M.S. and M.G.; visualization, M.S. and M.G.; project administration, M.S. and M.G.; funding acquisition, M.S and M.G. All authors have read and agreed to the published version of the manuscript.

Funding: This research was partially funded by Croatian Science Foundation, grant number UIP-2019-04-3749 (ARES project-Assessment and rehabilitation of existing structures-development of contemporary methods for masonry and timber structures). This work was supported by the University of Zagreb for the project: "Advanced photogrammetry and remote sensing methods for environmental change monitoring" (Grant No. RS4ENVIRO).

Conflicts of Interest: The authors declare no conflicts of interest. The funders had no role in the design of the study; in the collection, analyses, or interpretation of data; in the writing of the manuscript, or in the decision to publish the results.

\section{References}

1. Barbieri, G.; Biolzi, L.; Bocciarelli, M.; Fregonese, L.; Frigeri, A. Assessing the seismic vulnerability of a historical building. Eng. Struct. 2013, 57, 523-535. [CrossRef]

2. Atalić, J.; Šavor Novak, M.; Uroš, M. Seismic risk for Croatia: Overview of research activities and present assessments with guidelines for the future. Appl. Sci. 2019, 71, 923-947.

3. Geiss, C.; Klotz, M.; Taubenb, H. Remote sensing for seismic building vulnerability assessment. In Proceedings of the Second European Conference on Earthquake Engineering and Seismology, Istanbul, Turkey, 25-29 August 2014.

4. Antolinc, D.; Žarni, R.; Stepinać, M.; Rajčič, V.; Krstevska, L.; Tashkov, L. Simulation of earthquake load imposed on timber-glass composite shear wall panel. In COST Action TU0905 Mid-Term Conference Structural Glass; Belis, J., Louter, C., Mocibob, D., Eds.; CRC Press: London, UK, 2013.

5. Fragiacomo, M.; Dujic, B.; Sustersic, I. Elastic and ductile design of multi-storey crosslam massive wooden buildings under seismic actions. Eng. Struct. 2011, 33, 3043-3053. [CrossRef]

6. Pejovic, J.; Jankovic, S. Seismic fragility assessment for reinforced concrete high-rise buildings in Southern Euro-Mediterranean zone. Bull. Earthq. Eng. 2016, 14, 185-212. [CrossRef]

7. Hancilar, U.; Taucer, F.; Corbane, C. Empirical fragility functions based on remote sensing and field data after the 12 January 2010 Haiti earthquake. Earthq. Spectra 2013, 27, 157-177. [CrossRef] 
8. Hancilar, U.; Çaktı, E.; Erdik, M. Earthquake performance assessment and rehabilitation of two historical unreinforced masonry buildings. Bull. Earthq. Eng. 2012, 10, 307-330. [CrossRef]

9. Mendes, N.; Lourenço, P.B. Sensitivity analysis of the seismic performance of existing masonry buildings. Eng. Struct. 2014, 11, 143-160. [CrossRef]

10. Stepinac, M.; Šušteršič, I.; Gavrić, I.; Rajčić, V. Seismic design of timber buildings: Highlighted challenges and future trends. Appl. Sci. 2020, 10, 1380. [CrossRef]

11. Bedon, C.; Amadio, C. Enhancement of the seismic performance of multi-storey buildings by means of dissipative glazing curtain walls. Eng. Struct. 2017, 152, 320-334. [CrossRef]

12. Kišiček, T.; Renić, T.; Lazarević, D.; Hafner, I. Compressive shear strength of reinforced concrete walls at high ductility levels. Sustainability 2020, 12, 4434. [CrossRef]

13. Manyika, J.; Chui, M.; Miremadi, M.; Bughin, J.; George, K.; Wilmott, P.; Dewhurst, M. A Future That Works: Automation, Employment, and Productivity. Available online: https: //www.semanticscholar.org/paper/A-future-that-works\%3A-automation\%2C-employment\%2C-andManyika-Chui/e3ac9558f18234cdf92b730a7386ff16d446a1af (accessed on 1 January 2017).

14. McKinsey Global Institute. Global Media Report 2014. Available online: https://www.mckinsey.com/ industries/technology-media-and-telecommunications/our-insights/global-media-report-2014 (accessed on 9 September 2014).

15. Machado, J.S.; Riggio, M.; D'Ayala, D. Assessment of structural timber members by non-and semi-destructive methods. Constr. Build. Mater. 2015, 101, 1155-1156. [CrossRef]

16. Stepinac, M.; Rajčić, V.; Barbalić, J. Inspection and condition assessment of existing timber structures. Gradjevinar 2017, 69, 1380. [CrossRef]

17. Stepinac, M.; Rajčić, V.; Honfi, D. Condition assessment of timber structures-Quantifying the value of information. In Tomorrow's Megastructures, Proceedings of the 40th International Association for Bridge and Structural Engineering Symposium (IABSE), Nantes, Italy, 19-21 September 2018; Curan Associates Inc.: Red Hook, NY, USA, 2018.

18. Lourenço, P.B. The ICOMOS methodology for conservation of cultural heritage buildings: Concepts, research and application to case studies. In Proceedings of the International Conference on Preservation, Maintenance and Rehabilitation of Historical Buildings and Structures, Tomar, Portugal, 19-21 June 2014. [CrossRef]

19. Borri, A.; Corradi, M.; De Maria, A.; Sisti, R. Calibration of a visual method for the analysis of the mechanical properties of historic masonry. Procedia Struct. Integr. 2018, 11, 418-427. [CrossRef]

20. Breysse, D.; Martínez-Fernández, J.L. Assessing concrete strength with rebound hammer: Review of key issues and ideas for more reliable conclusions. Mater. Struct. Constr. 2014, 47, 1589-1604. [CrossRef]

21. Sýkora, M.; Diamantidis, D.; Holický, M.; Marková, J.; Rózsás, Á. Assessment of compressive strength of historic masonry using non-destructive and destructive techniques. Constr. Build. Mater. 2018, 193, 196-210. [CrossRef]

22. Agreed, K.; Klysz, G.; Balayssac, J.P. Location of reinforcement and moisture assessment in reinforced concrete with a double receiver GPR antenna. Constr. Build. Mater. 2018, 188, 1119-1127. [CrossRef]

23. Sajid, S.H.; Ali, S.M.; Carino, N.J.; Saeed, S.; Sajid, H.U.; Chouinard, L. Strength estimation of concrete masonry units using stress-wave methods. Constr. Build. Mater. 2018, 163, 518-528. [CrossRef]

24. Mesquita, E.; Martini, R.; Alves, A.; Antunes, P.; Varum, H. Non-destructive characterization of ancient clay brick walls by indirect ultrasonic measurements. J. Build. Eng. 2018, 19, 172-180. [CrossRef]

25. Martini, R.; Carvalho, J.; Barraca, N.; Arêde, A.; Varum, H. Advances on the use of non-destructive techniques for mechanical characterization of stone masonry: GPR and sonic tests. Procedia Struct. Integr. 2017, 5, 1108-1115. [CrossRef]

26. Valluzzi, M.R.; Cescatti, E.; Cardani, G.; Cantini, L.; Zanzi, L.; Colla, C.; Filippo, C. Calibration of sonic pulse velocity tests for detection of variable conditions in masonry walls. Constr. Build. Mater. 2018, 192, 272-286. [CrossRef]

27. Wai-Lok Lai, W.; Dérobert, X.; Annan, P. A review of Ground Penetrating Radar application in civil engineering: A 30-year journey from Locating and Testing to Imaging and Diagnosis. NDT E Int. 2018, 96, 58-78. [CrossRef]

28. Meola, C. Infrared thermography of masonry structures. Infrared Phys. Technol. 2007, 49, 228-233. [CrossRef] 
29. Parivallal, S.; Kesavan, K.; Ravisankar, K.; Sundram, B.A.; Ahmed, A.K.F. Evaluation of in-situ stress in masonry structures by flat jack technique. In Proceedings of the National Seminar Exhibition on Non-Destructive Evaluation (NDE 2011), Chennai, India, 8-10 December 2011; pp. 8-13.

30. Simões, A.; Gago, A.; Bento, R.; Lopes, M. Flat-Jack Tests on Old Masonry Buildings. In Proceedings of the 15th International Conference on Experimental Mechanics, Porto, Portugal, 22-27 July 2012; Volume 1, p. 3056.

31. Ramos, L.F.; De Roeck, G.; Lourenço, P.B.; Campos-Costa, A. Damage identification on arched masonry structures using ambient and random impact vibrations. Eng. Struct. 2010, 32, 146-162. [CrossRef]

32. Invernizzi, S.; Lacidogna, G.; Lozano-Ramírez, N.E.; Carpinteri, A. Structural monitoring and assessment of an ancient masonry tower. Eng. Fract. Mech. 2018, 210, 429-443. [CrossRef]

33. Stepinac, M.; Kisicek, T.; Renić, T.; Hafner, I.; Bedon, C. Methods for the assessment of critical properties in existing masonry structures under seismic loads-the ARES project. Appl. Sci. 2020, 10, 1576. [CrossRef]

34. Negro, P.; Mola, E. A performance based approach for the seismic assessment and rehabilitation of existing RC buildings. Bull. Earthq. Eng. 2017, 15, 3349-3364. [CrossRef]

35. Lourenco, P.; Karanikoloudis, G. Seismic behavior and assessment of masonry heritage structures. Needs in engineering judgement and education. RILEM Tech. Lett. 2019, 3, 114-120. [CrossRef]

36. Piazza, M.; Riggio, M. Visual strength-grading and NDT of timber in traditional structures. J. Build. Apprais. 2008, 3, 267-296. [CrossRef]

37. Dietsch, P.; Kreuzinger, H. Guideline on the assessment of timber structures: Summary. Eng. Struct. 2011, 33, 2983-2986. [CrossRef]

38. Croce, P.; Beconcini, M.L.; Formichi, P.; Cioni, P.; Landi, F.; Mochi, C.; Giuri, R. Shear modulus of masonry walls: A critical review. Procedia Struct. Integr. 2018, 11, 339-346. [CrossRef]

39. Fox, M.; Coley, D.; Goodhew, S.; De Wilde, P. Thermography methodologies for detecting energy related building defects. Renew Sustain. Energy Rev. 2014, 40, 296-310. [CrossRef]

40. Usamentiaga, R.; Venegas, P.; Guerediaga, J.; Vega, L.; Molleda, J.; Bulnes, F.G. Infrared thermography for temperature measurement and non-destructive testing. Sensors 2014, 14, 12305-12348. [CrossRef] [PubMed]

41. Kylili, A.; Fokaides, P.A.; Christou, P.; Kalogirou, S.A. Infrared thermography (IRT) applications for building diagnostics: A review. Appl. Energy 2014, 134, 531-549. [CrossRef]

42. Milovanović, B.; Pečur, I.B. Review of active IR thermography for detection and characterization of defects in reinforced concrete. J. Imaging 2016, 2, 11. [CrossRef]

43. Carpentier, O.; Chartier, O.; Antczak, E.; Descamp, T.; van Parys, L. Active and quantitative infrared thermography using frequential analysis applied to the monitoring of historic timber structures. In Proceedings of the International Conference on Structural Health Assessment of Timber Structures, Wroclaw, Poland, 11 September 2015; pp. 61-70.

44. Khan, F.; Bolhassani, M.; Kontsos, A.; Hamid, A.; Bartoli, I. Modeling and experimental implementation of infrared thermography on concrete masonry structures. Infrared Phys. Technol. 2015, 69, 228-237. [CrossRef]

45. Mader, D.; Blaskow, R.; Westfeld, P.; Weller, C. Potential of UAV-Based laser scanner and multispectral camera data in building inspection. Int. Arch. Photogramm. Remote Sens. Spat. Inf. Sci-ISPRS Arch. 2016, B1, 1135-1142. [CrossRef]

46. Valença, J.; Gonçalves, L.M.S.; Júlio, E. Damage assessment on concrete surfaces using multi-spectral image analysis. Constr. Build. Mater. 2013, 40, 971-981. [CrossRef]

47. Ellenberg, A.; Kontsos, A.; Bartoli, I.; Pradhan, A. Masonry crack detection application of an unmanned aerial vehicle. In Proceedings of the International Conference Computing in Civil and Building Engineering, Orlando, FL, USA, 23-25 June 2014. [CrossRef]

48. Santos, B.O.; Valença, J.; Júlio, E. Detection of cracks on concrete surfaces by hyperspectral image processing. Autom. Vis. Insp. Mach. Vis. II 2017, 188, 72-79. [CrossRef]

49. Santos, B.O.; Valença, J.; Júlio, E. Automatic mapping of cracking patterns on concrete surfaces with biological stains using hyper-spectral images processing. Struct. Control Health Monit. 2019, 26. [CrossRef]

50. Khan, A.; Gupta, S.; Gupta, S.K. Multi-hazard disaster studies: Monitoring, detection, recovery, and management, based on emerging technologies and optimal techniques. Int. J. Disaster Risk Reduct. 2020, 47, 101642. [CrossRef]

51. De Silva, L.O.; de Bandeira, R.A.M.; Campos, V.B.G. Proposal to planning facility location using UAV and geographic information systems in a post-disaster scenario. Int. J. Disaster Risk Reduct. 2019, 36, 101080. [CrossRef] 
52. Kim, H.; Lee, J.; Ahn, E.; Cho, S.; Shin, M.; Sim, S.H. Concrete crack identification using a UAV incorporating hybrid image processing. Sensors 2017, 26, 2052. [CrossRef] [PubMed]

53. Grazzini, A.; Chiabrando, F.; Foti, S.; Sammartano, G.; Spanò, A. A multidisciplinary study on the seismic vulnerability of St. Agostino Church in Amatrice following the 2016 seismic sequence. Int. J. Archit. Herit. 2019, 3058, 885-902. [CrossRef]

54. Federman, A.; Santana Quintero, M.; Kretz, S.; Gregg, J.; Lengies, M.; Ouimet, C.; Laliberte, J. UAV photgrammetric workflows: A best practice guideline. In Proceedings of the International Archives of the Photogrammetry, Remote Sensing and Spatial Information Services (ISPRS Archives), 26th International CIPA Symposium, Ottawa, CA, Canada, 28 August-1 September 2017. [CrossRef]

55. Barrile, V.; Candela, G.; Fotia, A. Point cloud segmentation using image processing techniques for structural analysis. In Proceedings of the Remote Sensing and Spatial Information Services (ISPRS Annual Photogrammetry), 2nd International Conference of Geomatics and Restoration, Milan, Italy, 8-10 May 2019. [CrossRef]

56. Achille, C.; Adami, A.; Chiarini, S.; Cremonesi, S.; Fassi, F.; Fregonese, L.; Taffurelli, L. UAV-based photogrammetry and integrated technologies for architectural applications-Methodological strategies for the after-quake survey of vertical structures in Mantua (Italy). Sensors 2015, 15, 15520-15539. [CrossRef]

57. Gomez, C.; Purdie, H. UAV-based photogrammetry and geocomputing for hazards and disaster risk monitoring-A review. Geoenviron. Disasters 2016, 3, 23. [CrossRef]

58. Lin, Y.S.; Chuang, R.Y.; Yen, J.Y.; Chen, Y.C.; Kuo, Y.T.; Wu, B.L.; Huang, S.-Y.; Yang, C.-J. Mapping surface breakages of the 2018 Hualien earthquake by using UAS photogrammetry. Terr. Atmos. Ocean Sci. 2019, 30, 351-366. [CrossRef]

59. Hirose, M.; Xiao, Y.; Zuo, Z.; Kamat, V.R.; Zekkos, D.; Lynch, J. Implementation of UAV localization methods for a mobile post-earthquake monitoring system. In Proceedings of the IEEE Work. Environmental Energy and Structural Monitoring Systems (EESMS 2015), Trento, Italy, 9-10 July 2015. [CrossRef]

60. Hudnut, K.W.; Brooks, B.A.; Scharer, K.; Hernandez, J.L.; Dawson, T.E.; Oskin, M.E.; Arrowsmith, J.R.; Goulet, C.A.; Blake, K.; Boggie, M.A.; et al. Airborne lidar and electro-optical imagery along surface ruptures of the 2019 ridgecrest earthquake sequence, Southern California. Seismol Res. Lett. 2020, 11, 3082. [CrossRef]

61. Jaydev, P.D.; Gregory, D.; Oussama, K.; Vijay, K. (Eds.) Experimental Robotics; Springer: Heidelberg, Germany, 2013; Volume 88, pp. 733-743. [CrossRef]

62. Benassi, F.; Dall'Asta, E.; Diotri, F.; Forlani, G.; Morra di Cella, U.; Roncella, R.; Santise, M. Testing accuracy and repeatability of UAV blocks oriented with gnss-supported aerial triangulation. Remote Sens. 2017, 9, 172. [CrossRef]

63. Stöcker, C.; Nex, F.; Koeva, M.; Gerke, M. Quality assessment of combined IMU/GNSS data for direct georeferencing in the context of UAV-based mapping. In Proceedings of the International Archives Photogrammetry Remote Sensing and Spatial Information Sciences (ISPRS Archives), Bonn, Germany, 4-7 September 2017. [CrossRef]

64. Jurjević, L.; Gašparović, M.; Milas, A.S.; Balenović, I. Impact of UAS image orientation on accuracy of forest inventory attributes. Remote Sens 2020, 12, 404. [CrossRef]

65. Tisdale, J.; Kim, Z.; Hedrick, J. Autonomous UAV path planning and estimation. IEEE Robot. Autom. Mag. 2009, 16, 35-42. [CrossRef]

66. Nex, F.; Remondino, F. UAV for 3D mapping applications: A review. Appl. Geomat. 2014, 6, 1-15. [CrossRef]

67. Navia, J.; Mondragon, I.; Patino, D.; Colorado, J. Multispectral mapping in agriculture: Terrain mosaic using an autonomous quadcopter UAV. In Proceedings of the International Conference Unmanned Aircraft System (ICUAS), Arlington, VA, USA, 7-10 June 2016. [CrossRef]

68. Luhmann, T.; Fraser, C.; Maas, H.G. Sensor modelling and camera calibration for close-range photogrammetry. ISPRS J. Photogramm. Remote Sens. 2016, 115. [CrossRef]

69. Kordić, B.; Gašparović, M.; Oberiter, B.L.; Đapo, A.; Vlastelica, G. Spatial data performance test of mid-cost UAS with direct georeferencing. Period Polytech. Civ. Eng. 2020, 52. [CrossRef]

70. Kaempchen, N.; Dietmayer, K. Data synchronization strategies for multi-sensor fusion. In Proceedings of the IEEE Conference of Intelligent Transportation System, Shanghai, China, 12-15 October 2003.

71. Gašparović, M. Radiometric Equalization of Textures on the Photorealistic 3D Models. Ph.D. Thesis, Faculty of Geodesy, Zagreb, Croatia, May 2015. 
72. Burggraaff, O.; Schmidt, N.; Zamorano, J.; Pauly, K.; Pascual, S.; Tapia, C.; Spyrakos, E.; Snik, F. Standardized spectral and radiometric calibration of consumer cameras. Opt. Express 2019, 14, 19075-19101. [CrossRef]

73. Kim, S.J.; Pollefeys, M. Robust radiometric calibration and vignetting correction. IEEE Trans. Pattern. Anal. Mach. Intell. 2008, 30, 562-576. [CrossRef]

74. Sinha, S.N.; Pollefeys, M. Synchronization and calibration of camera networks from silhouettes. In Proceedings of the 17th International Conference on Pattern Recognition, Cambridge UK, 23-26 August 2004. [CrossRef]

75. Huck, T.; Westenberger, A.; Fritzsche, M.; Schwarz, T.; Dietmayer, K. Precise timestamping and temporal synchronization in multi-sensor fusion. In Proceedings of the IEEE Intelligent Vehicles Symposium (IV), Baden-Baden, Germany, 5-9 June 2011. [CrossRef]

76. Rischbeck, P.; Elsayed, S.; Mistele, B.; Barmeier, G.; Heil, K.; Schmidhalter, U. Data fusion of spectral, thermal and canopy height parameters for improved yield prediction of drought stressed spring barley. Eur. J. Agron. 2016, 78, 44-59. [CrossRef]

77. Liao, W.; Huang, X.; Van Coillie, F.; Gautama, S.; Pižurica, A.; Philips, W.; Liu, H.; Zhu, T.; Shimoni, M.; Moser, G.; et al. Processing of multiresolution thermal hyperspectral and digital color data: Outcome of the 2014 IEEE GRSS data fusion contest. IEEE J. Sel. Top Appl. Earth Obs. Remote Sens. 2015, 2984-2996. [CrossRef]

78. Remondino, F.; Gruen, A. Multi-sensor 3D documentation of the Maya site of Copan. In Proceedings of the 22nd CIPA Symposium, Kyoto, Japan, 11-15 October 2009.

79. Mathews, A.J.; Jensen, J.L.R. Visualizing and quantifying vineyard canopy LAI using an unmanned aerial vehicle (UAV) collected high density structure from motion point cloud. Remote Sens. 2013, 5, 2164-2183. [CrossRef]

80. Jay, S.; Rabatel, G.; Hadoux, X.; Moura, D.; Gorretta, N. In-field crop row phenotyping from 3D modeling performed using Structure from Motion. Comput. Electron. Agric. 2015, 110, 70-77. [CrossRef]

81. Lucieer, A.; Jong, S.M.d.; Turner, D. Mapping landslide displacements using Structure from Motion (SfM) and image correlation of multi-temporal UAV photography. Prog. Phys. Geogr. 2014, 38, 97-116. [CrossRef]

82. Sarakinou, I.; Papadimitriou, K.; Georgoula, O.; Patias, P. Underwater 3D modeling: Image enhancement and point cloud filtering. Int. Arch. Photogramm. Remote Sens. Spat. Inf. Sci.-ISPRS Arch. 2016, 41. [CrossRef]

83. Zhang, Z.; Gerke, M.; Vosselman, G.; Yang, M.Y. Filtering photogrammetric point clouds using standard lidar filters towards dtm generation. ISPRS Ann. Photogramm. Remote Sens. Spat. Inf. Sci. 2018, 2. [CrossRef]

84. Zeybek, M.; Şanlığlu, İ. Point cloud filtering on UAV based point cloud. Meas. J. Int. Meas. Confed. 2019, 133, 99-111. [CrossRef]

85. Pintus, R.; Gobbetti, E.; Callieri, M.; Dellepiane, M. Techniques for Seamless Color Registration and Mapping on Dense 3D Models, 1st ed.; Springer: Berlin/Heidelberg, Germany, 2017; pp. 355-376. [CrossRef]

86. Dvorožňák, M.; Nejad, S.S.; Jamriška, O.; Jacobson, A.; Kavan, L.; Sýkora, D. Seamless Reconstruction of Part-Based High-Relief Models from Hand-Drawn Images. Available online: https://www.cs.utah.edu/ $\sim\{\}$ ladislav/dvoroznak18seamless/dvoroznak18seamless.pdf (accessed on 17 August 2018).

87. Duro, D.C.; Franklin, S.E.; Dubé, M.G. A comparison of pixel-based and object-based image analysis with selected machine learning algorithms for the classification of agricultural landscapes using SPOT-5 HRG imagery. Remote Sens. Environ. 2012, 118, 259-272. [CrossRef]

88. Tzotsos, A. A support vector machine approach for object based image. In Proceedings of the 1st International Conference Object-Based Image Analysis, Salzburg, Austria, 4-5 July 2006.

89. Gašparović, M.; Zrinjski, M.; Barković, Đ.; Radočaj, D. An automatic method for weed mapping in oat fields based on UAV imagery. Comput. Electron. Agric. 2020, 173, 105385. [CrossRef]

90. Peña, J.M.; Gutiérrez, P.A.; Hervás-Martínez, C.; Six, J.; Plant, R.E.; López-Granados, F. Object-based image classification of summer crops with machine learning methods. Remote Sens. 2014, 6, 5019-5041. [CrossRef]

91. Gašparović, M.; Zrinjski, M.; Gudelj, M. Automatic cost-effective method for land cover classification (ALCC). Comput. Environ. Urban Syst. 2019, 76, 1-10. [CrossRef]

92. Jawak, S.D.; Luis, A.J. A spectral index ratio-based Antarctic land-cover mapping using hyperspatial 8-band WorldView-2 imagery. Polar Sci. 2013, 7, 18-38. [CrossRef]

93. Morsy, S.; Shaker, A.; El-Rabbany, A.; Larocque, P.E. Airborne multispectral lidar data for land-cover classification and land/water mapping using different spectral indexes. ISPRS Ann. Photogramm. Remote Sens. Spat. Inf. Sci. 2016, 3. [CrossRef] 
94. Hall-Beyer, M. Practical guidelines for choosing GLCM textures to use in landscape classification tasks over a range of moderate spatial scales. Int. J. Remote Sens. 2017, 38, 1312-1338. [CrossRef]

95. Kuffer, M.; Pfeffer, K.; Sliuzas, R.; Baud, I. Extraction of slum areas from VHR imagery using GLCM variance. IEEE J. Sel. Top. Appl. Earth. Obs. Remote Sens. 2016, 9, 1830-1840. [CrossRef]

96. Raiffa, H.; Schlaifer, R. Applied Statistical Decision Theory, 1st ed.; Harvard University Press: Boston, MA, USA, 1961.

97. Haralick, R.M.; Dinstein, I.; Shanmugam, K. Textural features for image classification. IEEE Trans. Syst. Man. Cybern. 1973, 2, 109-130. [CrossRef]

98. Gašparović, M.; Dobrinić, D. Comparative assessment of machine learning methods for urban vegetation mapping using multitemporal sentinel-1 imagery. Remote Sens. 2020, 12, 1952. [CrossRef]

99. Gavarini, C. Seismic risk in historical centers. Soil Dyn. Earthq. Eng. 2001, 21, 459-466. [CrossRef]

100. Papathoma-Köhle, M. Vulnerability curves vs. Vulnerability indicators: Application of an indicator-based methodology for debris-flow hazards. Nat. Hazards Earth. Syst. Sci. 2016, 18. [CrossRef]

101. Goretti, A.; Di Pasquale, G. An overview of post-earthquake damage assessment in Italy. In Proceedings of the EERI Invitational Workshop. An Action to Develop Earthquake Damage and Loss Data Protocols, Pasadena, CA, USA, 19-20 September 2002.

(C) 2020 by the authors. Licensee MDPI, Basel, Switzerland. This article is an open access article distributed under the terms and conditions of the Creative Commons Attribution (CC BY) license (http://creativecommons.org/licenses/by/4.0/). 